\title{
STUDI OBESITAS SENTRAL PADA MAHASISWA PRODI KESEHATAN MASYARAKAT UNIVET BANGUN NUSANTARA SUKOHARJO
}

\author{
Kartika Pibriyanti \\ Program Studi Kesehatan Masyarakat, Fakultas Kesehatan Masyarakat, Universitas \\ Veteran Bangun Nusantara Sukoharjo. Jl. Letjend. Sujono Humardani No 1 Kampus \\ Jombor, Sukoharjo 57521 \\ Email: Dkartika.02@gmail.com
}

\begin{abstract}
ABSTRAK
Obesitas sentral dianggap sebagai faktor risiko yang berkaitan erat dengan beberapa penyakit kronis karena berupa penumpukan lemak berlebih pada jaringan lemak subkutan dan lemak viseral perut. Tujuan penelitian ini untuk mengetahui faktor risiko obesitas sentral pada Mahasiswa Prodi Kesehatan Masyarakat, Universitas Veteran Bangun Nusantara. Jenis penelitian observasional analitik dengan rancangan cross sectional. Populasi adalah semua mahasiswa yang berstatus aktif dengan pemilihan sampel dilakukan secara proporsi dengan simple random sampling. Analisis data dilakukan secara deskriptif dan dianalisis secara bivariat dengan uji chi square. Hasil penelitian menunjukkan dari 72 mahasiswa $11,1 \%$ termasuk dalam kategori obesitas sentral, 55,9\% berusia $\geq 20$ tahun, 70,8\% jenis kelamin perempuan, $17,7 \%$ memiliki kebiasaan merokok, $12,5 \%$ aktivitas fisik ringan dan $22,2 \%$ kondisi mental emosional terganggu. Simpulan penelitian tidak dapat membuktikan hubungan antara usia, jenis kelamin, kebiasaan merokok, aktivitas fisik, kondisi mental emosional dengan kejadian obesitas sentral pada mahasiswa Prodi Kesehatan Masyarakat, Universitas Veteran Bangun Nusantara.
\end{abstract}

Kata kunci : obesitas sentral, umur, jenis kelamin, aktivitas fisik, kondisi mental emosional

\begin{abstract}
Central obesity is considered as a risk factor that is closely related to several chronic diseases because of the accumulation of excess fat in subcutaneous fat tissue and abdominal visceral fat. The purpose of this study was to determine the central obesity risk factors in students of Public Health Study Program, Veteran Bangun Nusantara University. The type of research used was analytic observational with a crosssectional design. The population was all students who were active with the selection of samples conducted in proportion with simple random sampling. Data were analyzed descriptively and bivariate by chi-square test. The results showed that from 72 students as many as $11.1 \%$ were included in the central obesity category. As many as $55.9 \%$ respondents were aged $\geq 20$ years. As many as $70.8 \%$ respondents were the female sex. As many as $17.7 \%$ respondents have a smoking habit. As much as $12.5 \%$ respondents performed the light
\end{abstract}


physical activity. As many as $22.2 \%$ respondents experienced mentalemotional disorders. Conclusions of the study could not prove the relationship between age, sex, smoking habits, physical activity, mental-emotional condition with the incidence of central obesity in students of Public Health Study Program, Veteran Bangun Nusantara University.

Keywords: central obesity, age, gender, physical activity, mentalemotional condition

\section{PENDAHULUAN}

WHO (2014) menyatakan pada tahun 2008 angka obesitas didunia sebesar $11,9 \%$ dan lebih dari 1,4 milyar remaja yang berusia 20 tahun atau lebih menderita overweight, dan penderita obesitas sebanyak 200 juta adalah remaja laki-laki dan 300 juta adalah remaja perempuan. Overweight dan obesitas adalah risiko terbesar penyebab kematian global. Sekitar 3.4 juta remaja meninggal setaip tahunnya karena kedua hal tesebut. Hal lain yang harus diperhatikan adalah $44 \%$ penderita diabetes, $23 \%$ penderita jantung dan antara $7-41 \%$ penderita kanker berhubungan dengan overweight dan obesitas. Obesitas sentral merupakan penumpukan lemak dalam tubuh bagian perut (Tchernof, A dan Despres, J. 2013). Berdasar data Balitbangkes (2013), secara nasional, prevalensi obesitas sentral adalah $26,6 \%$, lebih tinggi dari prevalensi pada tahun $2007(18,8 \%)$.

Peningkatan prevalensi obesitas sentral berdampak pada munculnya berbagai penyakit degeneratif. Penyebab utama masalah obesitas adalah lingkungan dan perubahan perilaku. Peningkatan proporsi lemak dan peningkatan densitas energi dalam diet, penurunan level aktivitas fisik dan peningkatan perilaku sedentary, merupakan faktor utama yang dapat meningkatkan berat badan pada populasi. Genetik, faktor biologi dan faktor individu lain seperti penghentian merokok, jenis kelamin, dan umur saling berinteraksi memengaruhi peningkatan berat badan (Sugianti dkk., 2009).

Mahasiswa merupakan kelompok usia dewasa awal. Pada umur 20-30 tahun diketahui terjadi penurunan pada massa jaringan bebas lemak dan peningkatan pada massa jaringan lemak (Tchernof, A dan Despres, J. 2013). Obesitas sentral banyak terjadi pada orang dewasa. Semakin meningkatnya usia, maka semakin tinggi risiko terjadinya obesitas sentral yang diakibatkan karena penumpukan lemak tubuh, terutama lemak perut (Pujiati, 2007).

Penelitian ini bertujuan untuk mengkaji hubungan beberapa faktor dengan kejadian obesitas sentral pada Mahasiswa Prodi Kesehatan Masyarakat Univet Bangun Nusantara Sukoharjo, meliputi faktor: umur, jenis kelamin, kebiasaan merokok, aktivitas fisik dan kondisi mental emosional.

\section{METODE PENELITIAN}

Penelitian ini adalah penelitian kuantitatif dengan menggunakan desain cross sectional. Populasi dalam penelitian ini adalah seluruh mahasiswa Prodi Kesehatan Masyarakat angkatan 20142016 Semester Genap 2016/2017 yang berstatus aktif sejumlah 544. Pemilihan sampel dilakukan secara proporsional berdasarkan angkatan. Proses pengambilan sampel pada setiap angkatan menggunakan metode probability sampling dengan teknik simple random sampling. Apabila terdapat responden 
yang tidak bersedia, maka akan di drop out dan dilakukan pengocokan kembali untuk memilih sampel sampai mencapai jumlah sampel minimal untuk tiap angkatan. Sehingga diperoleh sejumlah 72 sampel.

Teknik pengumpulan data variabel obesitas sentral dilakukan dengan cara melakukan pengukuran lingkar perut dengan kategori obesitas sentral jika pada laki-laki ukurannya $>90 \mathrm{~cm}$, dan pada perempuan $>80 \mathrm{~cm}$. Variabel umur berisiki obesitas sentral jika $\geq 20$ tahun, jenis kelamin pada laki-laki lebih berisiko, kebiasaan rokok dikategorikan iya dan tidak, aktivitas fisik dikategorikan aktivitas berat, aktivitas sedang dan aktivitas ringan, serta kondisi mental emosional dikategorikan terganggu dan normal, yang mana pengumpulan data pada variabel bebas tersebut dilakukan dengan cara wawancara.

Analisis data dilakukan secara deskriptif dan dianalisis secara bivariat dengan uji chi square.

\section{HASIL DAN PEMBAHASAN}

Data distribusi obesitas sentral pada mahasiswa Fakultas Kesehatan Masyarakat Angatan 2014-2016 dapat dilihat pada Tabel 1.
Tabel 1. Distribusi Obesitas Sentral

\begin{tabular}{|c|c|c|c|}
\hline No & Variabel & $\begin{array}{c}\text { Frekuensi } \\
\text { (n) }\end{array}$ & $\begin{array}{c}\text { Persentase } \\
(\%)\end{array}$ \\
\hline \multirow[t]{4}{*}{1.} & Obesitas & & \\
\hline & Sentral & & \\
\hline & $\mathrm{Ya}$ & 8 & $11,1 \%$ \\
\hline & Tidak & 64 & $88,9 \%$ \\
\hline \multirow[t]{3}{*}{2.} & Umur & & \\
\hline & Berisiko & 41 & $56,9 \%$ \\
\hline & $\begin{array}{l}\text { Tidak } \\
\text { berisiko }\end{array}$ & 31 & $43,1 \%$ \\
\hline \multirow[t]{3}{*}{3.} & $\begin{array}{l}\text { Jenis } \\
\text { Kelamin }\end{array}$ & & \\
\hline & Perempuan & 51 & $70,8 \%$ \\
\hline & Laki-laki & 21 & $29,2 \%$ \\
\hline \multirow[t]{3}{*}{4.} & $\begin{array}{l}\text { Kebiasaan } \\
\text { Merokok }\end{array}$ & & \\
\hline & $\mathrm{Ya}$ & 12 & $16,7 \%$ \\
\hline & Tidak & 60 & $83,3 \%$ \\
\hline \multirow[t]{4}{*}{5.} & $\begin{array}{l}\text { Aktivitas } \\
\text { Fisik }\end{array}$ & & \\
\hline & Ringan & 9 & $12,5 \%$ \\
\hline & Sedang & 13 & $18,1 \%$ \\
\hline & Berat & 50 & $69,4 \%$ \\
\hline \multirow[t]{3}{*}{6.} & $\begin{array}{l}\text { Kondisi } \\
\text { Mental } \\
\text { Emosional }\end{array}$ & & \\
\hline & Terganggu & 16 & $22,2 \%$ \\
\hline & Normal & 56 & $77,8 \%$ \\
\hline
\end{tabular}

Hasil analisis univariat menunjukkan bahwa sebagian besar mahasiswa $64 \quad(88,9 \%)$ tidak obesitas sentral. Obesitas sentral dapat menyebabkan gangguang kesehatan, seperti diebetes mellitus tipe 2, dislipidemia, penyakit kardiovaskular, hipertensi, kanker dan sindrom metabolik (Tchernof \& Despres, 2013). Laki-laki dikatakan mengalami obesitas sentral apabila memiliki lingkar pinggang (LP) > $90 \mathrm{~cm}$ dan wanita LP $>80 \mathrm{~cm}$ (WHO, 2008). Diketahui pengukuran lingkar pinggang dapat menggambarkan penimbunan lemak dalam tubuh karena berhubungan dengan lemak pada bagian subkutan dan viseral perut (Power \& Jay, 2008). Hasil penelitian Mogre dkk. (2015) menunjukkan bahwa $10,8 \%$ mahasiswa mengalami obesitas sentral, studi terhadap mahasiswa Fakultas Kedokteran dan Ilmu Kesehatan di Temala, Ghana. 
Hasil analisis usia menunjukkan bahwa sebagian besar mahasiswa berisiko mengalami obesitas sentral $41(56,9 \%)$. Umur merupakan faktor prediksi dari terjadinya obesitas sentral (Veghari dkk., 2010). Perubahan umur berkaitan dengan peningkatan distribusi jaringan lemak yang ditandai dengan meningkatnya ukuran lingkar pinggang seseorang (Tchernof \& Despres, 2013).

Hasil analisis menunjukkan bahwa sebagian besar mahasiswa jenis kelamin perempuan $51(70,8 \%)$. Proporsi lemak pada laki-laki banyak terdapat pada bagian atas tubuh, seperti bagian abdominal atau perut, sedangkan proporsi lemak pada perempuan lebih banyak pada bagian bawah tubuh, seperti pada pinggang dan panggul (Pujiati, 2010). Di Indonesia, prevalensi obesitas sentral pada usia > 15 tahun banyak dialami oleh perempuan $42,1 \%$, sedangkan laiki-laki sebesar 11,3\% (Balitbangkes, 2013).

Hasil analisis menunjukkan bahwa sebagian besar mahasiswa tidak memiliki kebiasaan merokok 60 (83,3\%). Perokok diketahui memilki rangsangan lapar yang lebih rendah dibandingkan yang tidak merokok. Seseorang yang berhenti merokok akan membuat sensasi makan bertambah sehingga menyebabkan berat badan bertambah (Pujiati, 2010)

Hasil analisis menunjukkan bahwa sebagian besar mahasiswa memilki aktivitas fisik berat 50 (60,4\%). Aktivitas fisik yang rutin dapat mendoring penurunan yang cukup besar pada jaringan lemak, bahkan tanpa adanya penurunan berat badan (Tchernof \& Despres, 2013).

Hasil analisis menunjukkan bahwa sebagian besar mahasiswa dalam keadaan kondisi mental emosional normal 56 (77,8\%). Kombinasi antara peningkatan kortisol dan asupan makan dapat mempengaruhi distribusi lemak dalam tubuh seseorang. Tchernof \& Despres (2013) menjelaskan bahwa seseorang yang mengalami stres dapat meningkatkan kadar kortisol dan mengaktifkan saraf simpatik. Peningkatan kortisol ini dapat mempengaruhi kerja otak. Seseorang yang mengalami stres akan mengirimkan stimulus ke otak dan kemudian otak akan mengirimkan sinyal ke tubuh untuk meningkatkan nafsu makan.

Berdasar usia, diperoleh hasil sebagian besar mahasiswa berisiko $(\geq 20$ tahun) mengalami obesitas sentral 41 $(56,9 \%)$. Umur merupakan faktor prediksi dari terjadinya obesitas sentral (Veghari $\mathrm{dkk}, 2010$ ). Perubahan umur berkaitan dengan peningkatan distribusi jaringan lemak yang ditandai dengan meningkatnya ukuran lingkar pinggang seseorang (Tchernof \& Despres, 2013).

Tabel 2. Hubungan umur dengan obesitas sentral

\begin{tabular}{|c|c|c|c|c|c|c|c|c|}
\hline \multirow{3}{*}{ Umur } & \multicolumn{4}{|c|}{ Obesitas } & \multirow{2}{*}{\multicolumn{2}{|c|}{ Total }} & \multirow{3}{*}{$p$-value } & \multirow{3}{*}{$C$} \\
\hline & \multicolumn{2}{|c|}{ Ya } & \multicolumn{2}{|c|}{ Tidak } & & & & \\
\hline & $\mathrm{n}$ & $\%$ & $\mathrm{n}$ & $\%$ & $\mathrm{n}$ & $\%$ & & \\
\hline Berisiko & 5 & 62,5 & 36 & 56,2 & 41 & 56,9 & & \\
\hline Tidak berisiko & 3 & 37,5 & 28 & 43,8 & 31 & 43,1 & 0,736 & 0,040 \\
\hline
\end{tabular}

Hasil analisis bivariat pada Tabel 2 menunjukkan bahwa tidak terdapat hubungan bermakna antara umur dengan kejadian obesitas sentral $(p>0,05)$. Hasil berbeda ditemukan oleh Christina D \&
Sartika AD (2011) bahwa responden $>40$ tahun memiliki risiko terjadinya obesitas lebih besar dibandingkan dengan responden $<40$ tahun. Kejadian obesitas sentral meningkat seiring dengan 
meningkatnya umur seseorang akibat penumpukan lemak tubuh, terutama lemak perut. Pada proses menua mengakibatkan kehilangan massa otot secara progresif dan proses ini terjadi sejak usia 40 tahun dengan penurunan metabolisme basal $2 \%$ per tahun. Peningkatan lemak tubuh telah dimulai sejak seseorang berusia 30 tahun sebanyak $2 \%$ per tahunnya. Hasil Riskesdas nasional tahun 2013 menemukan bahwa kejadian obesitas sentral terbanyak pada usia 45-54 tahun yaitu $36,9 \%$. Perbedaan hasil penelitian diduga karena standar dan rentan usia yang berbeda. Pada usia sekitar 20 tahun belum terjadi akumulasi maksimal penumpukan lemak perut.

Sebagian besar mahasiswa, berjenis kelamin perempuan 51 (70,8\%). Proporsi lemak pada laki-laki banyak terdapat pada bagian atas tubuh, seperti bagian abdominal atau perut, sedangkan proporsi lemak pada perempuan lebih banyak pada bagian bawah tubuh, seperti pada pinggang dan panggul (Pujiati, 2010). Di Indonesia, prevalensi obesitas sentral pada usia > 15 tahun banyak dialami oleh perempuan $42,1 \%$, sedangkan laki-laki sebesar 11,3\% (Balitbangkes, 2013).

Tabel 3. Hubungan Jenis kelamin dengan Obesitas Sentral

\begin{tabular}{|c|c|c|c|c|c|c|c|c|}
\hline \multirow{3}{*}{ Jenis kelamin } & \multicolumn{4}{|c|}{ Obesitas } & \multirow{2}{*}{\multicolumn{2}{|c|}{ Total }} & \multirow{3}{*}{ p-value } & \multirow{3}{*}{$C$} \\
\hline & \multicolumn{2}{|c|}{ Ya } & \multicolumn{2}{|c|}{ Tidak } & & & & \\
\hline & n & $\%$ & $\mathbf{n}$ & $\%$ & $\mathbf{n}$ & $\%$ & & \\
\hline Laki-laki & 3 & 37,5 & 18 & 28,1 & 21 & 29,2 & & \\
\hline Perempuan & 5 & 62,5 & 46 & 71,9 & 51 & 70,8 & 0,582 & 0,065 \\
\hline
\end{tabular}

Hasil bivariat Tabel 3 menunjukkan bahwa tidak terdapat hubungan bermakna antara jenis kelamin dengan kejadian obesitas sentral $(p>0,05)$. Berbeda dari hasil penelitian Veghari dkk (2010) terdapat 2471 penduduk dewasa di Iran bagian utara, $57,2 \%$ wanita dan $15,8 \%$ laki-laki mengalami obesitas sentral. Di Indonesia, prevalensi obesitas sentral pada usia > 15 tahun banyak dialami oleh perempuan $(42,1 \%)$, sedangkan pada lakilaki 11,3\% (Balitbangkes, 2013).

Perbedaan teori yang diacu dengan beberapa hasil penelitian sebelumnya diduga karena ada perubahan gaya hidup mahasiswa. Lokasi penelitian termasuk di daerah perkotaan dimana mayoritas mahasiswa tinggal (kos) di sekitar lokasi penelitian. Terutama kebiasaan makan anak kos, lokasi hidup di kota yang serba praktis memungkinkan sulit menghindari fast food, dengan membeli makanan di luar atau makanan jadi untuk konsumsi harian daripada memasak. Banyaknya pedagang jajanan di sekitar kampus turut memicu mahasiswa, terutama mahasiswa perempuan lebih sering jajan dimana jajanan tersebut termasuk makanan tinggi energi (bakso bakar, seblak, sosis, siomai dan lain lain).

Hasil penilaian kebiasaan merokok, menunjukkan bahwa sebagian besar mahasiswa tidak memiliki kebiasaan merokok 60 (83,3\%). Merokok diketahui memiliki rangsangan lapar yang lebih endah dibandingkan yang tidak merokok. Seseorang yang berhenti merokok akan membuat sensasi makan bertambah sehingga menyebabkan berat badan bertambah (Pujiati, 2010). 
Tabel 4. Hubungan kebiasaan merokok dengan obesitas sentral

\begin{tabular}{|c|c|c|c|c|c|c|c|c|}
\hline \multirow{3}{*}{$\begin{array}{l}\text { Kebiasaan } \\
\text { merokok }\end{array}$} & \multicolumn{4}{|c|}{ Obesitas } & \multirow{2}{*}{\multicolumn{2}{|c|}{ Total }} & \multirow{3}{*}{$p$-value } & \multirow{3}{*}{$C$} \\
\hline & \multicolumn{2}{|c|}{ Ya } & \multicolumn{2}{|c|}{ Tidak } & & & & \\
\hline & $\mathbf{n}$ & $\%$ & n & $\%$ & $\mathbf{n}$ & $\%$ & & \\
\hline Ya & 1 & 12,5 & 11 & 17,2 & 12 & 16,7 & & \\
\hline Tidak & 7 & 87,5 & 53 & 82,2 & 60 & 83,3 & 0,737 & 0,039 \\
\hline
\end{tabular}

Analisis bivariat pada Tabel 4, menunjukkan bahwa tidak terdapat hubungan bermakna antara kebiasaan merokok dengan kejadian obesitas sentral ( $p>0,05)$. Diketahui sebagian besar sampel berjenis kelamin perempuan yang cenderung untuk tidak memiliki kebiasaan merokok. Hasil penelitian Sugianti dkk. (2009), menemukan bahwa kebiasaan merokok berhubungan negatif dengan obesitas sentral dan prevalensi obesitas sentral lebih banyak ditemukan pada sampel tidak merokok. Hubungan kebiasaan merokok dengan kejadian obesitas sentral masih kontroversial. Penelitian sebelumnya menemukan bahwa kebiasaan merokok berhubungan positif dengan kejadian obesitas sentral. Ketidakkonsistenan ini diduga karena pemilihan jenis desain studi, bias informasi dan kelemahan metode pengukuran. Seseorang yang tidak memiliki kebiasaan merokok harus memperhatikan pola makan dan gaya hidup.

Hasil penelitian menunjukkan bahwa sebagian besar mahasiswa memilki aktivitas fisik berat 50 (60,4\%). Aktivitas fisik yang rutin dapat mendorong penurunan yang cukup besar pada jaringan lemak, bahkan tanpa adanya penurunan berat badan (Tchernof \& Despres, 2013).

Tabel 5. Hubungan aktivitas fisik dengan obesitas sentral

\begin{tabular}{|c|c|c|c|c|c|c|c|c|}
\hline \multirow{3}{*}{$\begin{array}{l}\text { Aktifitas } \\
\text { fisik }\end{array}$} & \multicolumn{4}{|c|}{ Obesitas } & \multirow{2}{*}{\multicolumn{2}{|c|}{ Total }} & \multirow{3}{*}{ p-value } & \multirow{3}{*}{$C$} \\
\hline & \multicolumn{2}{|c|}{ Ya } & \multicolumn{2}{|c|}{ Tidak } & & & & \\
\hline & $\mathbf{n}$ & $\%$ & $\mathbf{n}$ & $\%$ & $\mathbf{n}$ & $\%$ & & \\
\hline Ringan & 2 & 25,0 & 7 & 10,9 & 9 & 12,5 & & \\
\hline Sedang & 1 & 12,5 & 12 & 18,7 & 13 & 18,0 & 0,511 & 0,135 \\
\hline Berat & 5 & 62,5 & 45 & 70,4 & 50 & 69,5 & & \\
\hline
\end{tabular}

Hasil bivariat pada Tabel 5, menunjukkan bahwa tidak terdapat hubungan bermakna antara kebiasaan merokok dengan kejadian obesitas sentral ( $p>0,05)$. Diketahui sebagian besar sampel memiliki aktivitas fisik berat sehingga tidak berisiko mengalami obesitas sentral. Dengan melakukan aktivitas fisik, maka energi yang masuk dapat digunakan dan terjadi peningkatan pengeluaran energi seseorang ketika melakukan aktivitas fisik. Hasil penelitian tidak sejalan dengan penelitian Pujiati (2010), terdapat hubungan antara aktivitas fisik dengan obesitas sentral pada orang dewasa. Aktivitas fisik yang rutin dapat mendorong penurunan yang cukup besar pada jaringan lemak, bahkan tanpa adanya penurunan berat badan (Tchernof \& Despres, 2013).

Perbedaan hasil penelitian diduga karena proporsi aktivitas fisik ringan, sedang dan berat yang dilakukan tidak berbeda signifikan. Berdasar hasil wawancara mayoritas mahasiswa memilih untuk berjalan kaki menuju kampus 
dengan durasi dan frekuensi tertentu sehingga pada hasil akumulasi perhitungan nilai METs tergolong aktivitas berat. Seseorang dikatakan memiliki aktivitas fisik berat apabila memenuhi kritria melakukan aktivitas fisik berat 3 hari atau lebih dalam seminggu atau memiliki minimal 1500 MET-detik/minggu dan melakukan kombinasi antara berjalan, melakukan aktivitas fisik sedang atau berat setiap hari atau minimal memiliki 3000 METdetik/minggu.

Hasil analisis menunjukkan bahwa sebagian besar mahasiswa dalam keadaan kondisi mental emosional normal 56 $(77,8 \%)$. Kombinasi antara peningkatan kortisol dan asupan makan dapat mempengaruhi distribusi lemak dalam tubuh seseorang. Tchernof \& Despres (2013) menjelaskan bahwa seseorang yang mengalami stres dapat meningkatkan kadar kortisol dan mengaktifkan saraf simpatik. Peningkatan kortisol ini dapat mempengaruhi kerja otak. Seseorang yang mengalami stres akan mengirimkan stimulus ke otak dan kemudian otak akan mengirimkan sinyal ke tubuh untuk meningkatkan nafsu makan.

Tabel 6. Hubungan kondisi mental emosional dengan obesitas sentral

\begin{tabular}{|c|c|c|c|c|c|c|c|c|}
\hline \multirow{3}{*}{ KME } & \multicolumn{4}{|c|}{ Obesitas } & \multirow{2}{*}{\multicolumn{2}{|c|}{ Total }} & \multirow{3}{*}{ p-value } & \multirow{3}{*}{$C$} \\
\hline & \multicolumn{2}{|c|}{ Ya } & \multicolumn{2}{|c|}{ Tidak } & & & & \\
\hline & $\mathbf{n}$ & $\%$ & $\mathbf{n}$ & $\%$ & $\mathbf{n}$ & $\%$ & & \\
\hline Terganggu & 1 & 12,5 & 15 & 23,4 & 16 & 22,2 & & \\
\hline Normal & 7 & 87,5 & 49 & 76,6 & 56 & 77,8 & 0,483 & 0,082 \\
\hline
\end{tabular}

Berdasar analisis bivariat pada Tabel 6, menunjukkan tidak terdapat hubungan bermakna antara kondisi mental emosional dengan kejadian obesitas sentral $(p>0,05)$. Data hasil penelitian menunjukkan bahwa sebagian besar mahasiswa dengan kondisi mental emosional normal, dan tidak berpotensi mengalami obesitas sentral. Dalam kondisi mental emosional normal, tidak berisiko terjadi kenaikan kadar kortisol dalam tubuh sehingga tidak mempengaruhi nafsu makan seseorang. Kondisi mental emosional merupakan suatu keadaan yang mengindikasikan individu mengalami suatu perubahan emosional yang dapat berkembang menjadi keadaan patologis apabila terjadi secara terus menerus (Idaiani dkk., 2009).

\section{KESIMPULAN}

Tidak ada hubungan signifikan antara usia, jenis kelamin, kebiasaan merokok, aktivitas fisik, kondisi mental emosional dengan kejadian obesitas sentral pada mahasiswa Prodi Kesehatan Masyarakat, Universitas Veteran Bangun Nusantara.

\section{DAFTAR PUSTAKA}

Badan Penelitian dan Pengembangan Kesehatan (Balitbangkes). (2013). Riset Kesehatan Dasar (Riskesdas) 2013. Kementerian Kesehatan Republik Indonesia. Jakarta. 
Christina, D., \& Sartika, R.A. (2011). Obesitas pada pekerja minyak dan gas. Departemen gizi kesehatan masyarakat fakultas kesehatan masyarakat Universitas Indonesia (dikutip 3 Oktober 2017). Available from:http://jurnalkesmas.ui.ac.id/index.php/kesmas/article/view/100/11

Idaini, S., Suhardi \& Kristanto, A. Y. 2009. Analisis gejala gangguan mental emosional penduduk Indonesia. Majalah Kedokteran. Vol 59 No 10.

Mogre, V, Nyaba, R., Aleyira, S., Sam, N.B. (2015). Demographic, dietary and physical activity predictors of generaland abdominal o besity among university students: a cross-sectional study. Springerplus. 15;4:226. doi: 10.1186/s40064-015-0999-2.

Pujiati S. (2007). Prevalensi dan faktor risiko obesitas sentral pada penduduk dewasa kota dan kabupaten Indonesia tahun 2007 .Tesis. Univesitas Indonesia (UI). (dikutip 16 Juni 2017). Depok.

Power, M. L., \& Schulkin, J. (2008). Sex differences in fat storage, fat metabolism, and the health risk from obesity : possible evolutionary origins. British Journal of Nutrition. Vol. 99, 931-9

Sugianti, E., Hardinsyah \& Afriansya, N. (2009). Faktor Risiko Obesitas Sentral pada Orang Dewasa di DKI Analisis lanjut data Riskesdas 2007. Gizi Indonesia. Jakarta.

Tchernof, A \& Despres, J. (2013). Pathophysiology of Human Visceral Obesity. Physiol Rev. 93.

Veghari, G. Sedaghat, M. Joshaghani, H. 2010. The prevalence and associated factors of central obesity in Norhern Iran. Iranian Cardiovascular Research Journal. Volume 4, Number 4, 2010, pp. 164-168(5).

WHO. (2008). Waist circumference and wait hip ratio : Report of a WHO expert consultation. World Health Organization. Geneva.

WHO. (2014). Obesity and Overweight. Cited from http://www.who. int/mediacentre/ factsheets/fs311/en/ di akses tanggal 9 Juni 2015. 